\title{
Salinity tolerance evaluation of barley germplasm for marginal soil utilization
}

\author{
Kico Dhima, ${ }^{1}$ Ioannis Vasilakoglou, ${ }^{2}$ Konstantinos Paschalidis, ${ }^{3}$ Nikitas Karagiannidis, ${ }^{1}$ \\ Ilias Ilias ${ }^{1}$ \\ ${ }^{1}$ Department of Agriculture, International Hellenic University, Echedoros; ${ }^{2}$ Department of Agriculture - \\ Agrotechnology, University of Thessaly, Larissa; ${ }^{3}$ Department of Agriculture, Hellenic Mediterranean \\ University, Heraklion, Greece
}

\begin{abstract}
Highlights
- $\quad$ The salinity tolerance of 184 barley varieties was investigated.

- There was great variability to salinity tolerance among barley germplasm.

- $\quad$ There were barley varieties which grown in saline soil without significant yield reduction.

- Barley could be an alternative crop system in soils with increased salinity.
\end{abstract}

\begin{abstract}
One greenhouse experiment was conducted to assess the tolerance to salinity and water deficit stresses of 184 barley varieties (breeding lines or registered varieties). Also, a 2-year field experiment was conducted to evaluate the growth and yield components of 16 of these varieties, representing tolerant, intermediate tolerant and susceptible ones, grown simultaneously in saline and nonsaline soils. In the greenhouse, the K-means cluster analysis shown that 17 varieties were tolerant, 72 varieties intermediate tolerant, 16 varieties intermediate susceptible and 79 varieties susceptible. In the field, soil salinity reduced the germination of the barley varieties except for the varieties ICB 100126, Scarlett and Meteor. Barley varieties grown in the saline soil produced 33.2-to
\end{abstract}

Correspondence: Ioannis Vasilakoglou, Department of Agriculture Agrotechnology, University of Thessaly, Geopolis of Larissa, 41500 Larissa, Greece. E-mail: vasilakoglou@uth.gr

Key words: Barley varieties; chlorophyll content; grain yield; soil salinity.

Acknowledgements: we greatly acknowledge financial support for this research from the European Union (European Regional Development Fund-ERDF) and the Greek National Fund.

See online Appendix for Supplementary material.

Received for publication: 9 February 2021.

Revision received: 5 May 2021.

Accepted for publication: 25 May 2021.

C Copyright: the Author(s), 2021

Licensee PAGEPress, Italy

Italian Journal of Agronomy 2021; 16:1830

doi:10.4081/ija.2021.1830

This article is distributed under the terms of the Creative Commons Attribution Noncommercial License (by-nc 4.0) which permits any noncommercial use, distribution, and reproduction in any medium, provided the original author(s) and source are credited.
$83.4 \%$ lower dry biomass, 0.0 -to $78.9 \%$ fewer ears and 0.0 -to $81.5 \%$ lower grain yield than those of varieties grown in the nonsaline soil. In the saline soil, the greatest grain yield was provided by the vars. Galt Brea 'S' and ICB 100126 (4.87 and $4.31 \mathrm{t} \mathrm{ha}^{-1}$, respectively), without significant differences between saline and non-saline soils. In most barley varieties, chlorophyll content and photosystem II quantum yield were greater under saline than under non-saline conditions. The results of this research indicated that, in barley germplasm, a remarkable genetic variation exists which would contribute to barley production in saline soils.

\section{Introduction}

Soil salinity and water deficit are the most important abiotic factors affecting crop yield worldwide. On a global scale, desertification and salinization have been dramatically increased affecting major crops in arable land and resulting in a more than $50 \%$ reduction in average yields (Ashraf et al., 2002; Wang et al., 2009; Li et al., 2010). The alterations in the cell membrane integrity, as well as the inhibition of photosynthesis and main enzymatic activities are among the plant metabolic processes affected by salt stress (Bor et al., 2003; Sairam and Tyagi, 2004; Parida and Das, 2005; Moradi and Ismail, 2007) manly because of the low osmotic potential of soil solution and the $\mathrm{Na}^{++}$accumulation (Ouzounidou et al., 2014). Therefore, it is worldwide important to be found germplasm tolerant to drought and salinity conditions, because this germplasm could significantly contribute to increased yield of crops cultivated in saline and semi-arid areas.

Barley (Hordeum vulgare L.), one of the most important cereal crops worldwide for feed, malt and human food, has been classified as one of the most valuable cereals because of its great genetic diversity resulting in great adaptability to marginal environments (characterized by salinity, drought or low temperature) (Katerji et al., 2006). The barley adaptability to a broad range of ecological conditions, as well as its genetic diversification, might have raised a rich gene pool resulting in tolerance to stresses. Barley high stomatal conductance, high maximum osmotic potential, vigorous growth and great tillering ability contribute to its high salt tolerance (Katerji et al., 2006). According to Xue et al. 
(2018), the successful barley germination under saline conditions could be attributed to the seed phytate content, which plays a role as an osmolyte source. Mahlooji et al. (2018) found that the barley salt-tolerant genotype maintained high photosynthesis rate and produced high grain yield mainly due to avoiding $\mathrm{Na}^{++}$accumulation in the aboveground tissues. Witzel et al. (2018) also reported that the differences in barley root architecture and root auxin redistribution were associated with salinity tolerance. Hammami et al. (2017) found that the barley genotypes selected from saline environments were more salt tolerant than the genotypes selected from non-saline environments. According to the same researchers, the barley salt tolerance was related to the plant $\mathrm{K}^{+}$and $\mathrm{Na}^{++}$content, as well as to relative water content. However, most of these classifications are based on observations of two, three or six varieties only (Sharma and Goyal, 2003; Katerji et al., 2006). Although the continued examination for traits associated with salt tolerance is a cutting edge point in cereals breeding, because it determines the cereals production and shortens the new varieties development (Binott et al., 2017), the varietal salt tolerance of barley under field conditions is a largely unexploited subject. Thus, the objective of this research was to investigate: i) the genetic variation in tolerance to salinity and water deficit of 184 barley varieties grown under greenhouse conditions; and ii) the productivity of 16 of these varieties ( 3 tolerant, 5 intermediate tolerant, 2 intermediate susceptible and 6 susceptible) in both low and high soil salinity, under Mediterranean field conditions. Therefore, the purpose of this study was the identification of barley varieties with the greatest tolerance to soil salinity, as well as the physiological traits associated with this tolerance.

\section{Materials and methods}

\section{Greenhouse experiment}

A pot experiment was conducted under greenhouse conditions in the 2011/12 growing season at the International Hellenic University Farm (Thessaloniki, Northern Greece) in order to evaluate the tolerance of 184 winter barley varieties (breeding lines or registered varieties), originating from 17 countries to combined salinity and water deficit stresses. The salt stress is strongly correlated with the water deficit because the first sense of plants in a saline environment is the osmotic stress which results in water uptake inability (Munns and Tester, 2008; Aliakbari et al., 2021). In the greenhouse, which was covered with a polyethylene sheet, the air temperature was maintained below $27^{\circ} \mathrm{C}$ during spring daytime by the use of one air cooling fan system. For the experiment, plastic pots of $20 \mathrm{~cm}$ diameter by $30 \mathrm{~cm}$ deep were filled each with $2 \mathrm{~kg}$ of a sandy loam (Typic Xeropsamment) soil. The soil characteristics were: clay at $56 \mathrm{~g} \mathrm{~kg}^{-1}$, silt at $180 \mathrm{~g} \mathrm{~kg}^{-1}$, sand at $764 \mathrm{~g} \mathrm{~kg}^{-1}$, organic matter at $9 \mathrm{~g} \mathrm{~kg}^{-1}, \mathrm{EC}_{\mathrm{se}}$ at $0.4 \mathrm{dS} \mathrm{m}^{-1}$ and $\mathrm{pH}\left(1: 1 \mathrm{H}_{2} \mathrm{O}\right)$ at 7.8. Pots were plugged in order to water draining be prohibited.

The experiment included a total of 2208 pots. Two days before seeding, the 1104 of these pots were treated with $200 \mathrm{ml}$ of a 150 $\mathrm{mM} \mathrm{NaCl}$ solution (creating saline conditions). The salt solution was applied once because the pots were plugged in order to avoid salt removal. In addition, the other 1104 pots were treated with 200 $\mathrm{ml}$ of deionized water (non-saline conditions). Seeds of 184 barley varieties were used in the experiment. Twelve seeds of each variety were seeded in each pot and covered with $1 \mathrm{~cm}$ of soil. The pots were irrigated with deionized water about every four days. Half the number of pots (552 treated with $\mathrm{NaCl}$ and 552 untreated) were irrigated with $40 \%$ of the soil water capacity, while the other half the number of pots ( 552 treated with $\mathrm{NaCl}$ and 552 untreated) were irrigated with the $80 \%$ of soil water capacity. During the night temperature was ranged from $10^{\circ} \mathrm{C}$ to $16^{\circ} \mathrm{C}$, while during the day temperature ranged from $18^{\circ} \mathrm{C}$ to $26^{\circ} \mathrm{C}$ (optimum for barley growth). Barley emergence was completed approximately 10 days after seeding. The treatments consisted of two levels of salinity ( 0 and $150 \mathrm{mM} \mathrm{NaCl}$, representing electrical conductivity 0.4 and $4.0 \mathrm{dS}$ $\mathrm{m}^{-1}$, respectively) and two levels of irrigation ( $40 \%$ and $80 \%$ of the soil water capacity).

The experimental design used was a completely randomized with three biological replications. The experiment was conducted twice (another 2208 pots were seeded and subjected to the treatments mentioned above). Barley germination [at 2 weeks after seeding (WAS)], tillering ability (at 7 WAS), height, total dry weight, ear number and grain weight (at 13 WAS) were assessed during the experiment.

\section{Field experiment}

\section{Experimental site}

Barley tolerance to soil salinity was also investigated during one experiment conducted in two fields during the 2012/13 and repeated in the same fields during the 2013/14 growing seasons. The experiments were established at the International Hellenic University Farm. The experimental area is located near the sea (over a distance of approximately $2.5 \mathrm{~km}$ ) and it is characterized as marginal, with great variability in soil salinity. Regarding the first field, the experiment was established in a saline, sandy loam

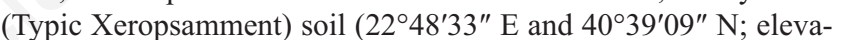
tion $0 \mathrm{~m}$ ). The characteristics of the soil were: clay at $56 \mathrm{~g} \mathrm{~kg}^{-1}$, silt at $180 \mathrm{~g} \mathrm{~kg}^{-1}$, sand at $764 \mathrm{~g} \mathrm{~kg}^{-1}$, organic matter at $9 \mathrm{~g} \mathrm{~kg}^{-1}$, potassium at $57.2 \mathrm{mg} \mathrm{kg}^{-1}$, sodium at $3130.6 \mathrm{mg} \mathrm{kg}^{-1}$ and soil $\mathrm{pH}$ at 8.1 $\left(1: 2 \mathrm{H}_{2} \mathrm{O}\right)$. Regarding the second field, the experiment was established in a non-saline, sandy loam soil (22 $48^{\prime} 23^{\prime \prime} \mathrm{E}$ and $40^{\circ} 39^{\prime} 32^{\prime \prime}$ $\mathrm{N}$; elevation $3 \mathrm{~m}$ ) consisting of clay at $76 \mathrm{~g} \mathrm{~kg}^{-1}$, silt at $280 \mathrm{~g} \mathrm{~kg}^{-1}$, sand at $644 \mathrm{~g} \mathrm{~kg}^{-1}$, organic matter at $8 \mathrm{~g} \mathrm{~kg}^{-1}$, potassium at $53.4 \mathrm{mg}$ $\mathrm{kg}^{-1}$, sodium at $394.4 \mathrm{mg} \mathrm{kg}^{-1}$ and soil $\mathrm{pH}$ at $7.6\left(1: 2 \mathrm{H}_{2} \mathrm{O}\right)$. The distance between the saline and non-saline fields was $550 \mathrm{~m}$. In both years, the soil analysis conducted in early October showed that the initial soil electrical conductivity in the saline field ranged from 7.3-to $11.5 \mathrm{dS} \mathrm{m}^{-1}$ (averaged $9.4 \mathrm{dS} \mathrm{m} \mathrm{m}^{-1}$ across samples), while in the non-saline field ranged from 0 -to $0.8 \mathrm{dS} \mathrm{m}^{-1}$ (averaged $0.4 \mathrm{dS} \mathrm{m}^{-1}$ across samples). The climatic data (mean monthly temperature and total monthly rainfall) which have been recorded near the experimental area (over a distance of approximately $500 \mathrm{~m}$ ) are shown in Figure 1.

\section{Treatments and experimental design}

Sixteen of the 184 varieties tested in the greenhouse experiment were used in the field experiment. The selection of these varieties was based on their tolerance to salinity and their seed availability. Especially, the barley varieties which achieved satisfactory germination and total weight, as well as grain production under saline conditions were defined as saline tolerant. In particular, three varieties [Galt Brea 'S' (GAL), ICB 100126 (ICB) and Scarlett (SCA)] were rated as tolerant to soil salinity (based on their germination, plant growth and grain yield in the greenhouse experiment), five varieties [Orgei/EH 165/Cross 270.2.3 (ORG), Ippolytos (IPP), Byzantio (BYZ), Prestige (PRE) and Meteor $(\mathrm{MET})$ ] were rated as intermediate tolerant, two varieties [Matico 'S'/LB Iran A-164 (MAT) and Tomillo 'S'/DS 4931 A-172 
(TOM)] were rated as intermediate susceptible and six varieties [Europa (EUR), Robur/WA 2196-68 (ROBW), Robur/J-126/OWB (ROBJ), 80.5060/Gloria 'S' A-196 (GLO), Franka/6/Mona/Nopal 'S' A-242 (FRA) and 4259/CI5831/Estate A-69 (EST)] were rated as susceptible. In both fields, $100 \mathrm{~kg}$ nitrogen $\mathrm{ha}^{-1}$ and $50 \mathrm{~kg}$ phosphorus $\mathrm{ha}^{-1}$ were applied as ammonium sulpho-phosphate (20-10$0)$. The fertilizers were incorporated into the soil prior to barley seeding. Additionally, $50 \mathrm{~kg}$ nitrogen $\mathrm{ha}^{-1}$ was applied in late March as ammonium nitrate (33.5-0-0). Barley varieties were seeded by hand in a density of 250 plants $\mathrm{m}^{-2}$ and in $16-\mathrm{cm}$ row spacing. In 2012 the barley was seeded on 12 November, while in 2013 on 20 November.

In the experiment, a randomized complete block design combined over locations (saline and non-saline fields) with four biological replicates was used. Twelve rows of one of the 16 barley varieties consisted in each plot. The plot size was $3 \times 2 \mathrm{~m}$; plots were separated by $1-\mathrm{m}$ wide alleys, while blocks were separated by 2-m wide alleys. In each growing season, weed [winter wild oat (Avena sterilis L.) and wild mustard (Sinapis arvensis L.)] control was achieved by the post-emergence application of iodosulfuron methyl-sodium \{methyl 4-iodo-2-[3-(4-methoxy-6-methyl-1,3,5triazin-2-yl)ureidosulfonyl]benzoate sodium salt $\}$ at $0.008 \mathrm{~kg} \mathrm{ha}^{-1}$ plus fenoxaprop-p-ethyl \{ethyl (2R)-2-[4-[(6-chloro-1,3-benzoxazol-2-yl)oxy]phenoxy]propanoate $\}$ at $0.064 \mathrm{~kg} \mathrm{ha}^{-1}$. Both herbicides were applied at the 3-to 4-leaves stage of winter wild oat, at the 2-to 4-leaves stage of wild mustard and at the 4-to 5-leaves stage (BBCH code 21-to 22; the beginning of tillering) (Lancashire et al., 1991) of barley. No irrigation was applied, according to the recommended production practices for the area.

\section{Data collection}

At 6 weeks after seeding (WAS) in each growing season, when barley completely emerged, crop stand was counted. Also, in middle March (16 WAS), when barley plants were at the 2-to 3-nodes growth stage (BBCH code 32-to 33), crop tiller number and dry weight were evaluated by harvesting plants in two $1-\mathrm{m}$ rows of barley $\left(0.32 \mathrm{~m}^{2}\right)$ of each plot.

During crop growing, the barley chlorophyll content index (CCI) and the barley quantum yield of photosystem II (Y) (evalu- ated at 16, 18, 20 and 22 WAS in soil saline and soil non-saline conditions) were determined for screening the effect of salinity stress on barley varieties (Belkhodja et al., 1994). A chlorophyll content meter (Opti-Sciences, model CCM-200, ADC BioScientific Ltd., UK) was used for the CCI determination. In particular, calibrated light-emitting diodes and receptors were used by the CCM-200 instrument in order to calculate the CCI. The CCI index is strongly correlated with the chlorophyll concentration in leaves as it is defined as the ratio of transmission at $931 \mathrm{~nm}$ to 653 $\mathrm{nm}$ through a leaf sample. The $\mathrm{Y}$ was calculated by the use of the $\mathrm{Y}=\left(\mathrm{F}_{\mathrm{m}^{\prime}}-\mathrm{F}_{\mathrm{s}}\right) / \mathrm{F}_{\mathrm{m}^{\prime}}$ equation. In particular, a chlorophyll fluorometer (MINI-PAM, Miniaturised Pulse-Amplitude-Modulated photosynthesis yield analyzer, Walz Co, Germany) was used for the chlorophyll $a$ fluorescence parameters. Especially, for the determination of fluorescence at steady-state $\left(\mathrm{F}_{\mathrm{s}}\right)$ and for the maximum fluorescence after saturation flash $\left(\mathrm{F}_{\mathrm{m}^{\prime}}\right)$, the measurements were made using light intensity of $0.15 \mu \mathrm{mol} \mathrm{m} \mathrm{m}^{-2} \mathrm{~s}^{-1}$, frequency of $0.6 \mathrm{kHz}$ and saturation pulse intensity of $16,000 \mu \mathrm{mol} \mathrm{m}^{-2} \mathrm{~s}^{-1}$ for $0.8 \mathrm{~s}$. In the two center rows of each plot and especially on the upper leaves of five marked plants, two measurements per plant were made. For both CCI and Y data, the average of ten measurements per plot was used for further data analyses.

At barley harvest (on June 20, 2013 and on June 25, 2014), plants of seven 1-m long rows $\left(1 \mathrm{~m}^{2}\right)$ in all plots were hand-harvested. Then, the barley yield components [total dry weight, ear number, grain yield and 1000-grains weight (at 14\% moisture content)] were evaluated.

\section{Statistical analyses}

For the greenhouse experiment (which was conducted twice) data were analyzed over repetition time, using a factorial approach (salinity $\times$ irrigation $\times$ barley variety). Also, K-means cluster analysis (using barley germination, total weight and grain yield data) was performed in order to categorize the 184 barley varieties into four groups (tolerant, intermediate tolerant, intermediate susceptible and susceptible).

For the barley field data (crop stand, tiller number and dry weight at 16WAS, as well as total dry weight, ear number, 1000grains weight and grain yield at harvest), a combined over loca-

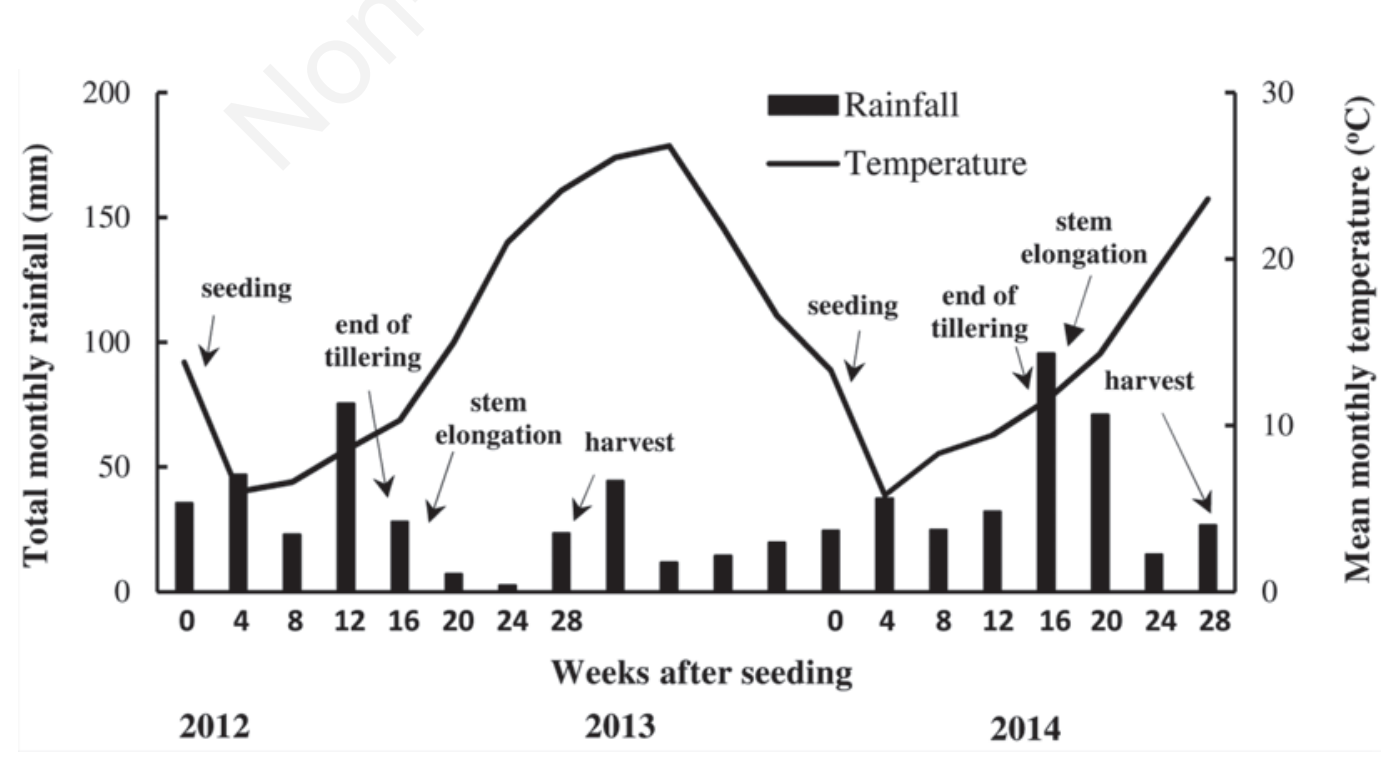

Figure 1. Total monthly rainfall and mean monthly temperature during the experiment. 
tions (saline and non-saline fields) and growing seasons, with the same locations each growing season but randomized, analysis of variance (ANOVA) was performed using a randomized complete block approach (barley varieties as fixed factor). Also, for the barley varieties $\mathrm{CCI}$ and $\mathrm{Y}$ data, a multivariate analysis of variance (MANOVA) was performed.

The Bartlett's test was used to examine the homogeneity of variances. The Statistical Package for the Social Sciences (SPSS, 2007) or the MSTAT (MSTAT-C, 1988) programs were used to conduct MANOVA and K-means cluster analyses or ANOVAs, respectively. The mean treatment differences were detected and separated by the use of the Fisher's protected least significant difference test procedures at $\mathrm{P}=0.05$.

\section{Results}

\section{Greenhouse experiment}

The ANOVAs performed for the greenhouse experiment data indicated that barley germination and growth traits were significantly affected by salinity $(\mathrm{P}<0.001)$, water deficit stress $(\mathrm{P}<0.001)$ and variety $(\mathrm{P}<0.001)$, as well as by salinity $\times$ water deficit $\times$ variety interaction $(\mathrm{P}<0.001)$. Because there was no significant repetition time $\times$ treatments interaction, the salinity $\times$ water deficit $x$ variation interaction means are presented in Table S1. Some barley varieties showed low germinability even under the conditions of $0 \mathrm{mM} \mathrm{Nacl}$ and $80 \%$ soil water content. Barley germination was the trait most reduced by the soil salinity. In particular, 58 of the barley varieties failed to emerge in the salinity treatment combined with irrigation equal to $40 \%$ of soil water capacity. Furthermore, salinity and water deficit reduced barley height, tillering ability and ear number (data not shown), as well as barley total weight and grain yield. In fact, 137 of the barley varieties did not produce grains in the salinity treatment combined with the $40 \%$ of soil water capacity irrigation. Also, in pots treated by salt and irrigated with the $80 \%$ of soil water capacity irrigation, 54 of the barley varieties did not produce grains.

The K-means cluster analysis performed, based on germination, total weight and grain weight data, showed that 17 varieties were tolerant, 72 varieties intermediate tolerant, 16 varieties intermediate susceptible and 79 varieties susceptible to the combined stress of salinity and water deficit (Figure 2, Table S1).

\section{Field experiment}

\section{Emergence and growth}

Barley stand at 6 WAS was affected by growing season $(\mathrm{P}<0.001)$, soil salinity $(\mathrm{P}<0.001)$, barley variety $(\mathrm{P}<0.001)$ and soil salinity $\mathrm{x}$ barley variety interaction $(\mathrm{P}<0.001)$. Barley tiller number at 16 WAS (end of tillering) was affected by growing season $(\mathrm{P}<0.05)$, soil salinity $(\mathrm{P}<0.001)$ and barley variety $(\mathrm{P}<0.001)$, while dry weight was affected by soil salinity $(\mathrm{P}<0.001)$, barley variety $(\mathrm{P}<0.001)$ and soil salinity $\mathrm{x}$ barley variety interaction $(\mathrm{P}<0.001)$. So, the soil salinity $\mathrm{x}$ barley variety interaction means are presented in Figure 3, as there was no significant growing season $\mathrm{x}$ treatments interaction (Table S2).

In the non-saline soil, the barley vars. Scarlett, Orgei/EH 165/Cross 270.2.3, Europa, 80.5060/Gloria 'S' A-196 and 4259/CI5831/Estate A-69 showed slightly lower plant number than that of the other varieties (Figure 3A). Averaged across varieties, barley plants that emerged in the saline soil were decreased by about $20 \%$ as compared with plants emerged in the non-saline soil (Figure $3 \mathrm{~A})$. In particular, the greatest emergence reduction by the soil salinity was observed in vars. Prestige (46\%), Galt Brea 'S' (31\%), Ippolytos (29\%), Franka/6/Mona/Nopal 'S' A-242 (27\%) and Robur/J-126/OWB (25\%). In contrast, the emergence of the var. Meteor was not affected by the soil salinity, while the emergence reduction of the vars. ICB 100126 and Scarlett was only $3.9 \%$ and $8.7 \%$, respectively. In the non-saline soil, barley emergence varied among varieties. The greatest plant number $\mathrm{m}^{-2}$ was recorded in vars. Galt Brea 'S' (264 plants m ${ }^{-2}$ ), Franka/6/Mona/Nopal'S' A-242 (227 plants $\left.\mathrm{m}^{-2}\right)$, Tomillo 'S'/DS4931 A-172 (220 plants $\left.\mathrm{m}^{-2}\right)$, and

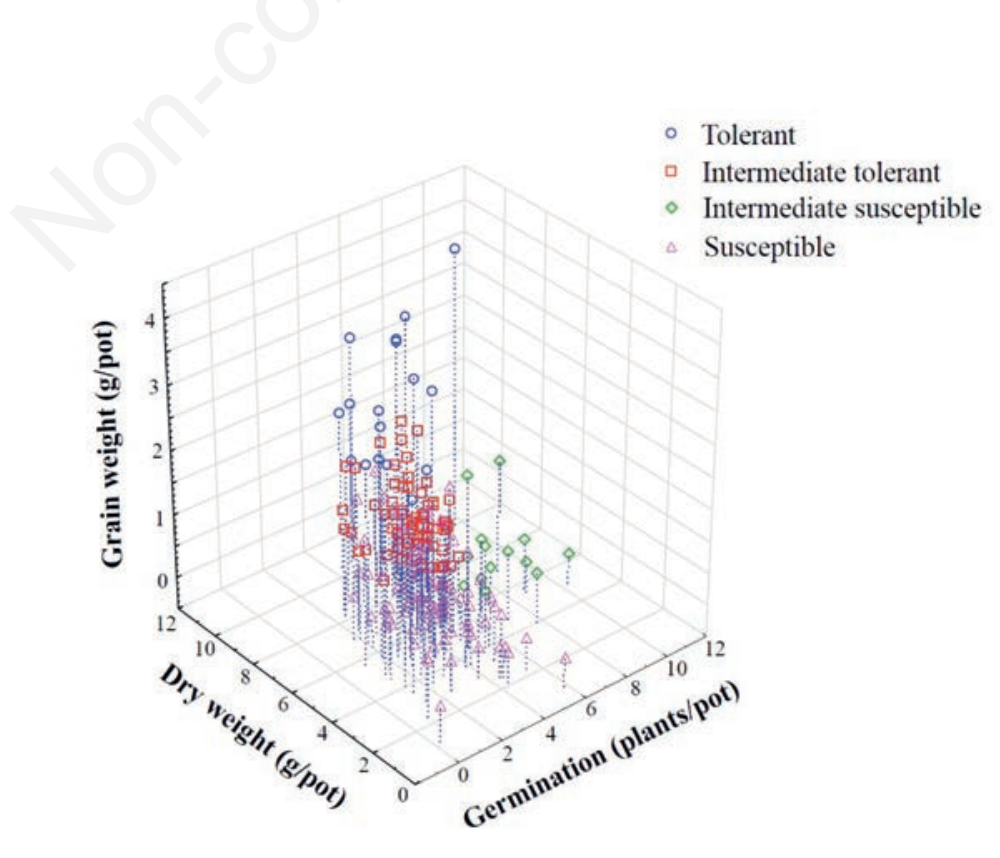

Figure 2. Susceptibility to salt and water deficit stresses of 184 barley varieties based on the K-means cluster analysis conducted for the germination ability, the total dry weight and the grain yield of plants grown in greenhouse conditions. 
Ippolytos (218 plants $\mathrm{m}^{-2}$ ).

The soil salinity dramatically decreased the barley tiller number (26-to 63.9\%) (Figure 3B). The greatest tiller number reduction was recorded in vars. 80.5060/Gloria 'S' A-196 (63.9\%), Orgei/EH 165/Cross 270.2.3 (61.2\%) and Tomillo 'S'/DS4931 A-172 $(60.2 \%)$. On the contrary, in the saline soil, the lowest tiller number reduction was observed in the vars. Galt Brea ' $\mathrm{S}$ ' and Byzantio (26\% and $30.9 \%$, respectively). In the non-saline soil, the barley vars. Ippolytos, Scarlett, ICB 100126, Byzantio, Matico 'S'/LB Iran A-164 and Tomillo 'S'/DS4931 A-172 showed the greatest stem number (indicating the tillering ability), while the vars. Europa, Robur/J-126/OWB, Franka/6/Mona/Nopal'S' A-196, 80.5060/Gloria 'S' A-196 and 4259/CI15831/Estate A-69 showed the lowest one.
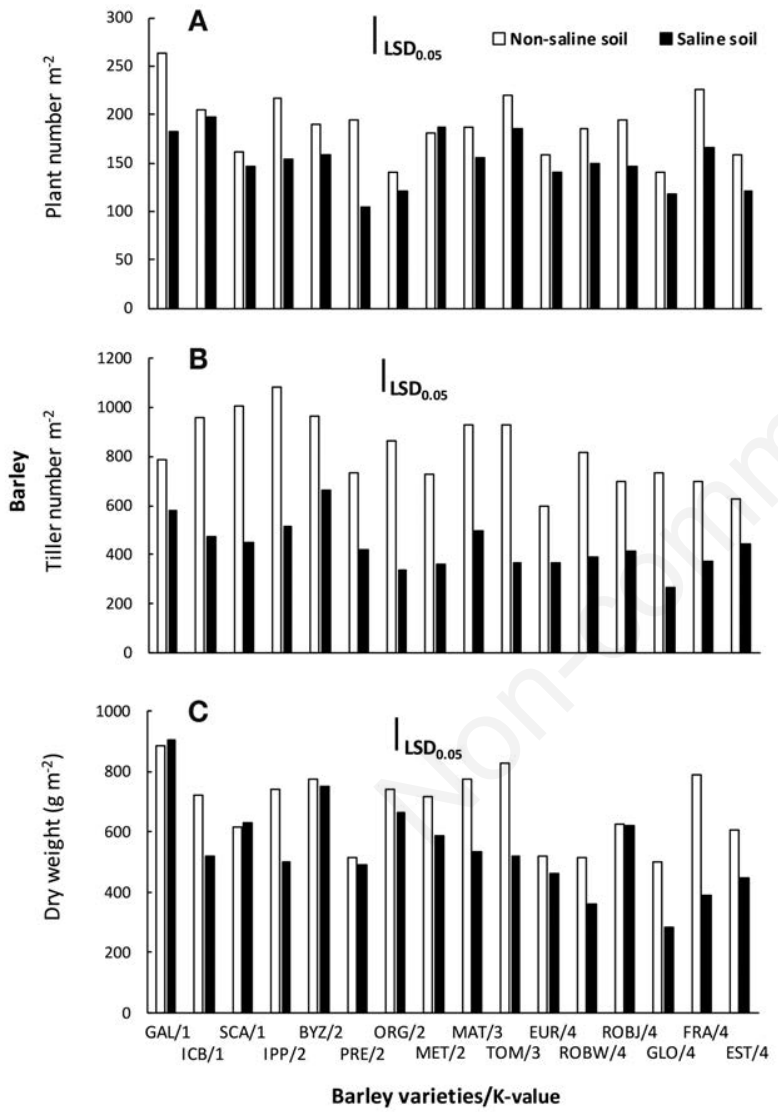

Figure 3. A-C) Stand at 6 weeks after seeding (WAS), as well as tiller number and dry weight (at 16 WAS) of 16 barley varieties grown in non-saline or saline soil. Means are averaged across two years. GAL=Galt Brea 'S', ICB=ICB 100126, SCA=Scarlett, ORG=Orgei/EH 165/Cross 270.2.3, IPP=Ippolytos, BYZ=Byzantio, $\quad$ PRE=Prestige, MET=Meteor, MAT=Matico 'S'/LB Iran A-164, TOM=Tomillo 'S'/DS4931 A-172, EUR=Europa, ROBW=Robur/WA 2196-68, ROBJ=Robur/J126/OWB, GLO=80.5060/Gloria 'S' A-196, FRA=Franka/6/Mona/Nopal ' $S$ ' A-242, EST=4259/CI5831/ Estate A-69.
Averaged across varieties, barley dry weight was decreased by 0-to $50.4 \%$ due to the soil salinity (Figure 3C). In particular, the dry weight of vars. Ippolytos, Tomillo 'S'/DS4931 A-172 and Franka/6/Mona/Nopal 'S' A-242 were significantly reduced (37.4to $50.4 \%$ ) in the saline soil. On the contrary, the dry weight of var. Galt Brea ' $S$ ' was not affected by the soil salinity. This was also the case for the vars. Orgei/EH 165/Cross 270.2.3, Byzantio, Prestige, Scarlett, Europa and Robur/J-126/OWB. However, the vars. Prestige and Europa provided low dry weight in both saline and non-saline conditions. In the non-saline soil, the greatest dry weight was provided by the vars. Galt Brea 'S', Ippolytos, Tomillo 'S'/DS4931 A-172 and Franka/6/Mona/Nopal'S' A-242.

\section{Physiological parameters}

The MANOVAs indicated that CCI and Y were significantly affected by soil salinity $(\mathrm{P}<0.001)$, barley variety $(\mathrm{P}<0.001)$ and soil salinity $\times$ barley variety interaction $(\mathrm{P}<0.001)$. So, the soil salinity $\mathrm{x}$ barley variety interaction means, averaged over the four sampling times, are presented in Figure 4.

Barley CCI was significantly greater in the saline soil than in the non-saline, as averaged over the four sampling times (Figure 4A) except for the vars. Galt Brea 'S', Scarlett and Tomillo 'S'/DS4931 A-172 whose CCI was not affected by soil salinity. In the saline soil, the vars. Galt Brea 'S', Byzantio, Scarlett, Europa and Robur/WA 2196-68 achieved the greatest CCI, while the vars. ICB 100126, Tomillo 'S'/DS4931 A-172, Robur/J-126/OWB,

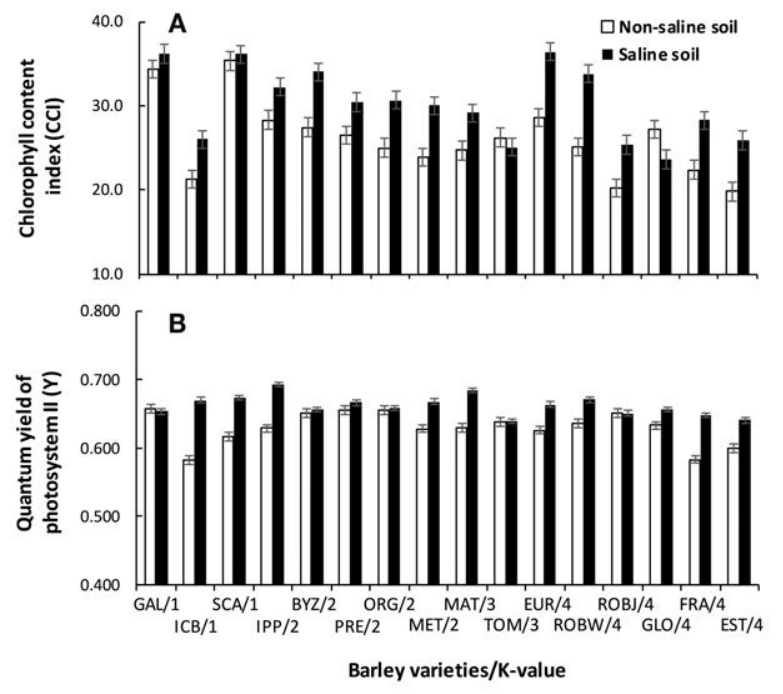

Figure 4. Chlorophyll content index (CCI) (A) and photosystem II quantum yield (Y) (B) of 16 barley varieties grown in saline or in non-saline soil. Means are averaged across two years and four sampling times. Error bars denote the standard error of four biological replicates. GAL=Galt Brea 'S', ICB=ICB 100126, SCA=Scarlett, ORG=Orgei/EH 165/Cross 270.2.3, IPP=Ippolytos, $B Y Z=$ Byzantio, $P R E=$ Prestige, $M E T=$ Meteor, MAT=Matico 'S'/LB Iran A-164, TOM=Tomillo 'S'/DS4931 A172, EUR=Europa, ROBW=Robur/WA 2196-68, ROBJ=Robur/J-126/OWB，GLO=80.5060/Gloria 'S' A-196, FRA=Franka/6/Mona/Nopal 'S' A-242, EST =4259/CI5831/ Estate A-69. 
80.5060/Gloria 'S' A-196 and 4259/CI15831/Estate A-69 the lowest. In the non-saline soil, the vars. Galt Brea ' $\mathrm{S}$ ' and Scarlett achieved the greatest CCI, while the vars. ICB 100126, Robur/J126/OWB and 4259/CI15831/Estate A-69 the lowest.

Barley $\mathrm{Y}$ values in the non-saline soil were equal or slightly lower than those in the saline one (Figure 4B). In the saline soil, the vars. Tomillo 'S'/DS4931 A-172 4259/CI15831/Estate A-69 achieved the lowest Y, while the vars. ICB 100126 and Franka/6/Mona/Nopal ' $S$ ' A-242 achieved the lowest $Y$ in the nonsaline soil.

\section{Yield components}

The ANOVAs performed for the barley yield components (total dry weight, ear number grain yield and 1000-grains weight) indicated in most cases significant growing season $(\mathrm{P}<0.001)$, soil salinity $(\mathrm{P}<0.001)$ and barley variety $(\mathrm{P}<0.001)$ effects, as well as significant soil salinity $\times$ barley variety interaction $(\mathrm{P}<0.001)$ (Table S2). As the ANOVAs for total dry weight and grain yield indicated no significant growing season $\mathrm{x}$ treatments interaction, the averaged between the growing season means are presented in Figure 5.

Barley plants grown in the saline soil produced 33.2 -to $83.4 \%$ lower dry biomass than barley plants grown in the non-saline soil (Figure 5A). In particular, the lowest total dry weight reduction was caused in the vars. Matico " $\mathrm{S}$ "/LB Iran A-164 and Orgei/EH $165 /$ Cross 270.2 .3 (33.2\% and $45.9 \%$, respectively). In contrast, the greatest total dry weight reduction (70.0-to 83.4\%) was caused in the vars. Tomillo 'S'/DS4931 A-172, Europa, 80.5060/Gloria 'S' A-196 and Franka/6/Mona/Nopal 'S' A-242. However, in the saline soil, the vars. Galt Brea ' $\mathrm{S}$ ', Ippolytos, Byzantio and Matico 'S'/LB Iran A-164 provided the greatest total dry weight (10.54-to $\left.12.01 \mathrm{t} \mathrm{ha}^{-1}\right)$. In the same conditions, the lowest total dry weight was recorded in the vars. $80.5060 /$ Gloria 'S' A-196 and Tomillo 'S'/DS4931 A-172 (3.31 and $5.65 \mathrm{t} \mathrm{ha}^{-1}$, respectively).

The flowering stage was observed at the same time for all barley varieties. However, in the saline soil, the barley varieties provided about $32 \%$ fewer ears than in the non-saline soil (Figure 5B). In particular, the ear number of the vars. Galt Brea 'S', Matico 'S'/LB Iran A-164, Robur/WA 2196-68, Franka/6/Mona/Nopal 'S' A-242 and 4259/CI15831/Estate A-69 was not affected by soil salinity. On the contrary, the ears of vars. Ippolytos, Prestige, Meteor, Europa and 80.5060/Gloria 'S' A-196 were reduced by 53, $47,48,58$ and $79 \%$, respectively, due to soil salinity. In the nonsaline soil, the barley vars. Galt Brea ' $S$ ', Ippolytos, Byzantio, Scarlett and Europa produced the greatest ear number, while the vars. Matico 'S'/LB Iran A-164, Tomillo 'S'/DS4931 A-172, Robur/WA 2196-68, Franka/6/Mona/Nopal 'S' A-242 and 4259/CI5831/Estate A-69 the lowest one. In saline soil, the greatest ear number was provided by the vars. Galt Brea 'S', ICB 100126 and Byzantio (475, 435 and 489 ears $\mathrm{m}^{-2}$, respectively), while the lowest by the vars. Tomillo 'S'/DS4931 A-172 and 80.5060/Gloria 'S' A-196 (189 and 89 ears m² ${ }^{-2}$, respectively).

Averaged among varieties, the soil salinity caused a $41 \%$ reduction in barley grain yield (Figure 5C). In the non-saline soil, the vars. Galt Brea 'S', Ippolytos, Byzantio, Scarlett, Meteor, Europa and 80.5060 /Gloria 'S' A-196 produced the greatest grain yield (5.55-to $\left.6.74 \mathrm{tha}^{-1}\right)$. The lowest grain yield was produced by the vars. Orgei/EH 165/Cross 270.2.3 and 4259/CI5831/Estate A69 (3.12 and $3.01 \mathrm{t} \mathrm{ha}^{-1}$, respectively). However, in the saline soil, the greatest grain yield was provided by the vars. Galt Brea ' $S$ ' and ICB 100126 (4.87 and $4.31 \mathrm{tha}^{-1}$, respectively). The greatest grain yield reduction (58.8-to $81.5 \%$ ), due to the soil salinity, was recorded in vars. Scarlett, Meteor, Europa and $80.5060 /$ Gloria 'S'
A-196, four of the seven varieties with the greatest grain yield in the non-saline field. The soil salinity did not significantly affect the grain yield of vars. Orgei/EH 165/Cross 270.2.3, Matico 'S'/LB Iran A-164 and 4259/CI5831/Estate A-69, but their grain yields were of the lowest among varieties.

Averaged among varieties, the soil salinity caused a $9.9 \%$ reduction on barley 1000-grains weight (Figure 5D) indicated that this yield component was the least affected. The greatest reduction was observed in vars. Scarlett and Franka/6/Mona/Nopal 'S' A-242 (16.7 and $15.4 \%$, respectively).
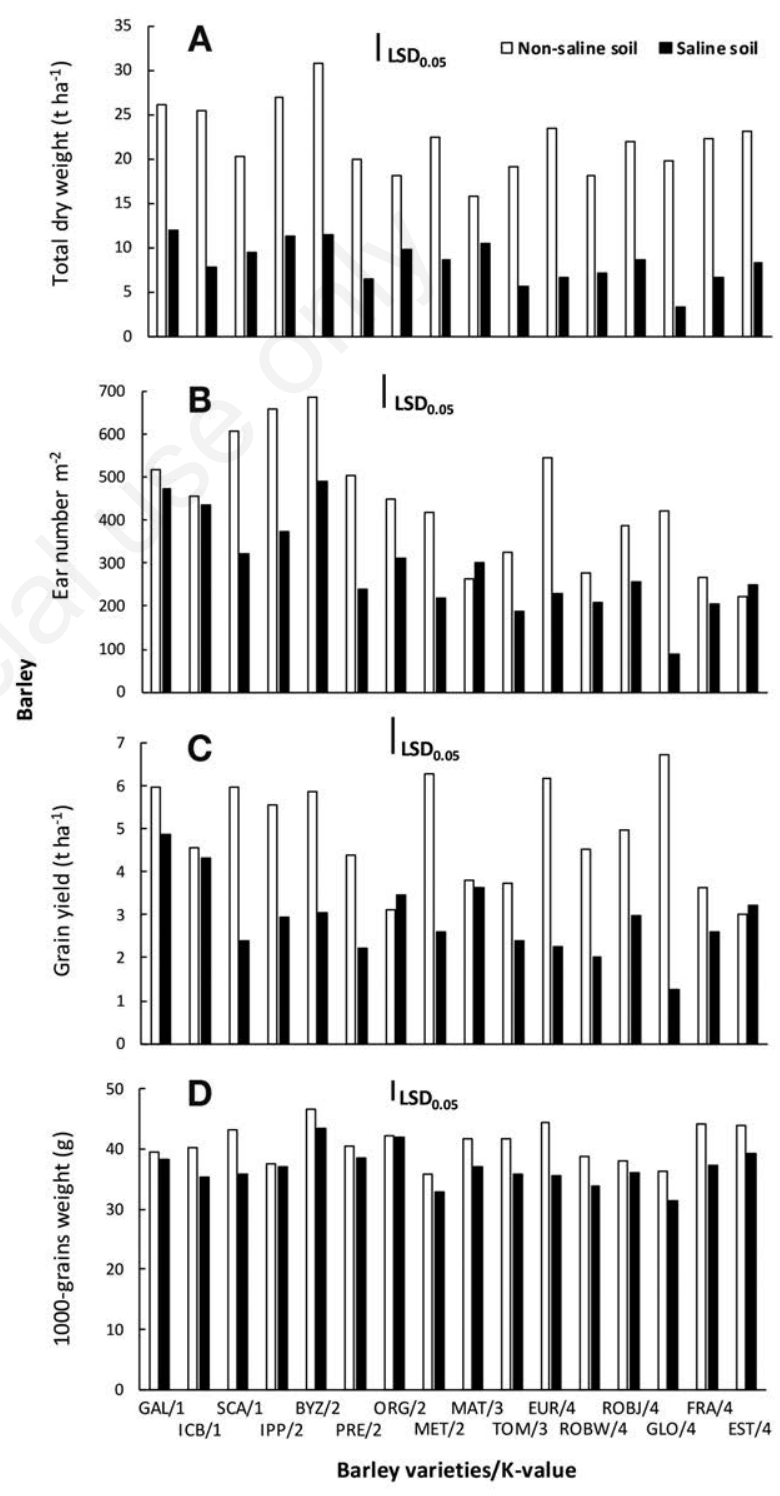

Figure 5. A-D) Total dry weight, ear number, grain yield and 1000-grains weight at harvest of the 16 barley varieties grown in non-saline or saline soil. Means are averaged across two years. GAL=Galt Brea ' $S$ ', ICB=ICB 100126, SCA=Scarlett, ORG=Orgei/EH 165/Cross 270.2.3, IPP=Ippolytos, $\mathrm{BYZ}=$ Byzantio, $\quad \mathrm{PRE}=$ Prestige, $\quad \mathrm{MET}=$ Meteor,$\quad \mathrm{MAT}=$ Matico 'S'/LB Iran A-164, TOM=Tomillo 'S'/DS4931 A-172, EUR=Europa, ROBW=Robur/WA 2196-68, ROBJ=Robur/J126/OWB, GLO=80.5060/Gloria 'S' A-196, FRA=Franka/ 6/Mona/Nopal 'S' A-242, EST =4259/CI5831/Estate A-69. 


\section{Discussion}

\section{Greenhouse experiment}

The seeds of barley varieties used in the pot experiment provided different germinability under the conditions of $0 \mathrm{mM} \mathrm{Nacl}$ and $80 \%$ soil water content. The data used for the K-means cluster analysis were averaged over the four treatment conditions. However, for some varieties, the final ranking may be affected by their low germinability.

Salinity, combined with water deficit stress, significantly reduced barley germination and growth traits. From the 184 barley varieties tested, the 137 ones did not produce grains in the salinity treatment, combined with irrigation equal to $40 \%$ of the soil water capacity. The barley plants in this treatment had not been normally developed, due to the variety salt susceptibility, and this fact was the main reason for the barley failure to produce grains. Similarly, Sbei et al. (2014), evaluating the salinity tolerance of 146 Asian barley accessions, found that there was a wide variation in salinity tolerance among the barley accessions and all traits were affected by salinity. Also, in previous studies (Royo and Aragues, 1999; Qiu et al., 2011; Long et al., 2013) it has been reported that great variation in salt tolerance exists among barley germplasm. According to Sbei et al. (2014), the screening for salinity is the basic and primordial step for plant breeding, needed to make crosses between susceptible and tolerant accessions, to get inbred lines and to identify the quantitative traits loci responsible for salinity tolerance.

Recently, Amarasinghe et al. (2019) reported a $\mathrm{Na}^{+} / \mathrm{H}^{+}$ exchanger (NHX) gene as responsible for high sheath $\mathrm{Na}^{+}$accumulation resulting in high salinity tolerance of barley. Also, a variation in expression pattern for genes related to terpenoid phenylpropanoid and flavonoid metabolism among barley varieties might contribute to salt stress tolerance. Wu et al. (2019) also found that the barley tolerance to salinity was contributed to the ability to sequester $\mathrm{Na}^{+}$in root vacuoles and simultaneously to prevent $\mathrm{Na}^{+}$ back-leak into cytosol. According to Derakhshani et al. (2020) the accumulation of the amino acids phenylalanine, tryptophan and tyrosine, as well as of the sugar acids galactaric acid and glucuronic acid were associated with the tolerance of the barley var. GrangeR in saline conditions. Zhu et al. (2020) found that two genes encoding the heat shock protein 90 and the protein kinase WAK were up-regulated in the saline-tolerant barley after $48 \mathrm{~h}$ exposure to $300 \mathrm{mM} \mathrm{NaCl}$. According to the authors, these proteins participate in $\mathrm{Ca}^{++}$signaling and hormone metabolism, maintaining the cell wall integrity. Also, Liu et al. (2014) found that the up-regulation of the slow anion channel genes HvSLAHI and HvSLAC1 correlated with barley tolerance in salinity.

According to the K-means cluster analysis performed for the germination, total dry weight and grain yield data, 17 varieties were rated as tolerant, 72 varieties as intermediate tolerant, 16 varieties as intermediate susceptible and 79 varieties as susceptible to salinity plus water deficit stress. These results suggested that the 17 tolerant barley varieties could be cultivated in saline or semiarid condition, as well as in fields where both stresses are presented. Sbei et al. (2014), evaluating the salinity tolerance of 146 barley accessions, found that the 19 accessions were tolerant to salinity.

In the current study, salinity was established before barley seeding. This fact permitted the evaluation of salinity stress effect on barley germination, representing the field conditions. However, in most of the experiments previously conducted (Katerji et al., 2006; Qiu et al., 2011; Long et al., 2013; Sbei et al., 2014), salinity stress was established in already emerged barley plants, restricting the ability to evaluate salinity effect on barley germination process.

\section{Field experiment}

The lower plant number of barley vars. Europa, 80.5060/Gloria 'S' A-196 and 4259/CI5831/Estate A-69 at 6 WAS could be partially attributed to their lower germinability as it was showed in the pot experiment. However, this was not the case for the vars. Scarlett and Orgei/EH 165/Cross 270.2.3. The vars. ICB 100126, Scarlett and Meteor achieved geater germination under saline conditions in the field than in the pots. This greater germination could be attribute to different soil conditions in the field (rainfall, aeration) which affect the salinity intensity.

The tiller number of all barley varieties was lower under saline than under non-saline soil. However, the total dry weight of six varieties was similar under both saline and non-saline conditions. This fact could be attributed to the greater biomass achieved by the fewer tillers, eliminating differences in total dry weight.

The lower grain yield achieved by the barley vars. Orgei/EH 165/Cross 270.2.3 and 4259/CI5831/Estate A-69 under non-saline soil conditions could be partially attributed to their slightly lower plant number. However, the vars. Scarlett, Europa and 80.5060 /Gloria 'S' A-196 achieved satisfactory grain yield under non-saline soil conditions may be due to their sufficient tiller and ear number.

In the second growing season, barley stand and dry weight at 16 WAS were about $19.6 \%$ and $23.6 \%$ (as averaged across salinity level and variety) lower, respectively, than those in the first growing season (data not shown), maybe due to the lower rainfall recorded during October 2013 to February 2014 (Figure 1). Also, in the second growing season, barley total weight and grain yield at harvest were about $21.3 \%$ and $19.5 \%$ (as averaged across salinity level and variety) lower, respectively, than those in the first growing season (data not shown), maybe due to the lower growth achieved until the stem elongation (at 16 WAS) in the second year.

In the saline soil selected for the current experiment, the electrical conductivity ranged from 7.3-to $11.5 \mathrm{dS} \mathrm{m}^{-1}$ (averaged $9.4 \mathrm{ds}$ $\mathrm{m}^{-1}$ across samples) as evaluated by soil sampling in the whole experimental area. Also, the positional effect was minimized by the plot randomization performed each growing season. According to Herrero and Pérez-Coveta (2005), a soil salinity like this presented in the experimental area significantly reduces the productivity of most crops in many coastal areas of Greece and other Mediterranean regions, because it exceeds their threshold salinity levels. Royo and Aragues (1999) evaluated the tolerance of 124 barley genotypes under controlled conditions found that significant differences were observed in response to the salinity, so that, the most tolerant variety had a threshold of $6.56 \mathrm{dS} \mathrm{m}^{-1}$ and the most susceptible one had a threshold of $1.34 \mathrm{dS} \mathrm{m}^{-1}$. Also, Niazi et al. $(1987,1992)$ reported that barley is a salt-tolerant crop; however, a great genetic variation exists for salt tolerance in barley varieties.

In the field, most barley varieties had greater chlorophyll content index under saline than under non-saline conditions, while, in most cases, the quantum yield of photosystem II did not differ between barley grown under saline and non-saline soil. However, Karanlik and Aslanyurek (2021), during a controlled conditions experiment, found that the barley (var. Kiral) chlorophyll-a and chlorophyll-b contents were reduced with increasing $\mathrm{NaCl}$ level from 0 to $150 \mathrm{mM}$. Aliakbari et al. (2021) found that the enhanced photosynthesis capability, mainly through regulation of Rubisco activase A expression and activity as well as the accumulation of proline were associated with barley tolerance to combined drought and salinity stress. 
Among the barley varieties evaluated in the current experiment, there were varieties whose grain yield was not significantly affected by the soil salinity. This was the case for the vars. Galt Brea 'S', ICB 100126, Orgei/EH 165/Cross 270.2.3, Byzantio, Prestige, Scarlett, Europa and Robur/J-126/OWB, indicating that these varieties have the ability to restrict the negative effect of salinity to their germination and tillering (tiller number production). According to Dell'Aversana et al. (2021) the salinity tolerance of some barley genotypes is attributed to their ability to compartmentalize high amounts of sodium in the roots and restricting the sodium entry into shoot at the seedling growth stage. Also, the fact that most of these varieties are registered varieties has relevant for breeders because they could easily access to these seeds. On the contrary, the grain yield reduction, due to soil salinity, of the most susceptible varieties tested, ranged from 58.8-to 81.5\%. Similarly, Tavakoli et al. (2010) found that the barley grain yield reduction ranged from 47.5 -to $79.6 \%$ when the salt susceptible varieties were grown under salt stress conditions caused by $200 \mathrm{mM} \mathrm{NaCl}$.

\section{Conclusions}

The results of this study indicated that there is great variability to salinity tolerance among barley germplasm. Barley traits such as successful germination, high biomass until stem elongation and high tillering ability are correlated with the high grain yield under field salinity conditions. Thus, the cultivation of barley varieties with the above-mentioned characteristics may be viable as an alternative, among other tolerant crops, crop system under increased salinity, especially in semi-saline and semi-arid Mediterranean fields. The results of this study could help in finding barley genetic material, such as the registered varieties Galt Brea ' $\mathrm{S}$ ' and ICB 100126, with a large capacity for tolerance to stress conditions of salinity, as well as distributing it to plant growers. Furthermore, by increasing barley tolerance to stress conditions of salinity would permit the use of problematic (saline) soils and regions, and thus, the increase of produced food and animal product.

\section{References}

Aliakbari M, Cohen SP, Lindlöf A, Shamloo-Dashtpagerdi R, 2021. Rubisco activase A (RcaA) is a central node in overlapping gene network of drought and salinity in Barley (Hordeum vulgare L.) and may contribute to combined stress tolerance. Plant Physiol. Bioch. 161:248-58.

Amarasinghe SL, Watson-Haigh NS, Byrt C, James R, Qiu J, Berkowitz O, Whelan J, Roy SJ, Gilliham M, Baumann U, 2019. Transcriptional variation is associated with differences in shoot sodium accumulation in distinct barley varieties. Environ. Exp. Bot. 166:103812.

Ashraf M, Arfan M, Shahbaz M, Ahmad A, Jamil A, 2002. Gas exchange characteristics and water relations in some elite okra cultivars under water deficit. Photosynthetica 40:615-20.

Belkhodja R, Morales F, Abadia A, Comez-Aparisi J, Abadia J, 1994. Chlorophyll fluorescence as a possible tool for salinity tolerance screening in barley (Hordeum vulgare L.). Plant Physiol. 104:667-73.

Binott JJ, Owuoche J, Bartels D, 2017. Physiological and molecular characterization of Kenyan barley (Hordeum vulgare L.) seedlings for salinity and drought tolerance. Euphytica
213:139

Bor M, Özdemir F, Türkan I, 2003. The effect of salt stress on lipid peroxidation and antioxidants in leaves of sugar beet Beta vulgaris L. and wild beet Beta maritime L. Plant Sci. 164:77-84.

Dell'Aversana E, Hessini K, Ferchichi S, Fusco GM, Woodrow P, Ciarmiello LF, Abdelly C, Carillo P, 2021. Salinity duration differently modulates physiological parameters and metabolites profile in roots of two contrasting barley genotypes. Plants 10:307.

Derakhshani Z, Bhave M, Shah RM, 2020. Metabolic contribution to salinity stress response in grains of two barley cultivars with contrasting salt tolerance. Environ. Exp. Bot. 179:104229.

Hammami Z, Gauffreteau A, BelhajFraj M, Sahli A, Jeuffroy M-H, Rezgui S, Bergaoui K, McDonnell R, Trifa Y, 2017. Predicting yield reduction in improved barley (Hordeum vulgare L.) varieties and landraces under salinity using selected tolerance traits. Field Crops Res. 211:10-8.

Herrero J, Pérez-Coveta O, 2005. Soil salinity changes over 24 years in a Mediterranean irrigated district. Geoderma 125:287-308.

Karanlik S, Aslanyurek D, 2021. Differences in dry matter production, chlorophyll and ion content of bread wheat, durum wheat, barley, oat and rye under salinity stress. Fresen. Environ. Bull. 29:10769-79.

Katerji N, van Hoorn JW, Hamdy A, Mastrorilli M, Fares C, Ceccarelli S, Grando S, Oweis T, 2006. Classification and salt tolerance analysis of barley varieties. Agric. Water Manag. $85: 184-92$.

Lancashire PD, Bleiholder H, Langelüddecke P, Stauss R, van den Boom T, Weber E, Witzen-Berger A, 1991. An uniform decimal code for growth stages of crops and weeds. Ann. Appl. Biol. 119:561-601.

Li R, Shi F, Fukuda K, Yang Y, 2010. Effects of salt and alkali stresses on germination, growth, photosynthesis and ion accumulation in alfalfa (Medicago sativa L.). Soil Sci. Plant Nutr. 56:725-33

Liu X, Mak M, Babia M, Wang F, Chen G, Veijanoski F, Wang G, Shabala S, Zhou M, Chen Z-H, 2014. Linking stomatal traits and expression of slow anion channel genes HvSLAH1 and HvSLAC1 with grain yield for increasing salinity tolerance in barley. Front. Plant Sci. 5:634.

Long NV, Dolstra O, Malosetti M, Kilian B, Graner A, Visser RG, van der Linden CG, 2013. Association mapping of salt tolerance in barley (Hordeum vulgare L.). Theor. Appl. Genet. 126:2335-51.

Mahlooji M, Seyed Sharifi R, Razmjoo J, Sabzalian MR, Sedghi M, 2018. Effect of salt stress on photosynthesis and physiological parameters of three contrasting barley genotypes. Photosynthetica 56:549-56.

Moradi F, Ismail AM, 2007. Responses of photosynthesis, chlorophyll fluorescence and ROS-scavenging systems to salt stress during seedling and reproductive stages in rice. Ann. Bot. 99:1161-73.

MSTAT-C, 1988. A microcomputer program for the design, management, and analysis of agronomic research experiments. Crop and Soil Sciences Department, Michigan State University, East Lansing, USA.

Munns R, Tester M, 2008. Mechanisms of salinity tolerance. Annu. Rev. Plant Biol. 59:651-81.

Niazi MLK, Mahmood K, Malik KA, 1987. Salt tolerance studies in different cultivars of barley (Hordeum vulgare L.). Pak. J. Bot. 19:17-27.

Niazi MLK, Mahmood K, Mujtaba SM, Malik KA, 1992. Salinity tolerance in different cultivars of barley (Hordeum vulgare L.). 
Biol. Plant. 34:465-9.

Ouzounidou G, Ilias IF, Giannakoula A, Theoharidou I, 2014. Effect of water stress and $\mathrm{NaCl}$ triggered changes on yield, physiology, biochemistry of broad bean (Vicia faba) plants and on quality of harvested pods. Biologia 69:1010-7.

Parida A, Das AB, 2005. Salt tolerance and salinity effects on plants. Ecotox. Environ. Safe. 60:324-49.

Qiu L, Wu D, Ali S, Cai S, Dai F, Jin X, Wu F, Zhang G, 2011. Evaluation of salinity tolerance and analysis of allelic function of HvHKT1 and HvHKT2 in Tibetan wild barley. Theor. Appl. Genet.122:695-703.

Royo A, Aragues R, 1999. Salinity - yield response functions of barley genotypes assessed with a triple line source sprinklers system. Plant Soil 209:9-20.

Sairam RK, Tyagi A, 2004. Physiology and molecular biology of salinity stress tolerance in plants. Curr. Sci. 86:407-21.

Sbei H, Shehzad T, Harrabi M, Okuno K, 2014. Salinity tolerance evaluation of Asian barley accessions (Hordeum vulgareL.) at the early vegetative stage. J. Arid Land Studies 24:183-6.

Sharma SK, Goyal SS, 2003. Progress in plant salinity resistance research: need for an integrative paradigm. In: S.S. Goyal et al. (eds) Crop production in saline environments. Food Products Press, NY, USA, pp 387-407.

SPSS (Statistical Package for the Social Sciences), 2007. SPSS Base 16.0 User's Guide. SPSS Inc., Chicago, IL, USA.
Tavakoli F, Vazan S, Moradi F, Shiran B, Sorkheh K, 2010. Differential response of salt-tolerant and susceptible barley genotypes to salinity stress. J. Crop Improv. 24:244-60.

Wang WB, Kim YH, Lee HS, Kim KY, Dengand XP, Kwak SS, 2009. Analysis of antioxidant enzyme activity during germination of alfalfa under salt and drought stresses. Plant Physiol. Biochem. 47:570-7.

Witzel K, Matros A, Møller ALB, Ramireddy E, Finnie C, Peukert M, Rutten T, Herzog A, Kunze G, Melzer M, KasparSchoenefeld S, Schmülling T, Svensson B, Mock H-P, 2018. Plasma membrane proteome analysis identifies a role of barley membrane steroid binding protein in root architecture response to salinity. Plant Cell Environ. 41:1311-30.

Wu H, Shabala L, Zhou M, Su N, Wu Q, Ul-Haq T, Zhu J, Mancuso S, Azzarello E, Shabala S, 2019. Root vacuolar $\mathrm{Na}^{+}$ sequestration but not exclusion from uptake correlates with barley salt tolerance. Plant J. 100:55-67.

Xue W, Gianinetti A, Jiang Y, Zhan Z, Kuang L, Zhao G, Yan J, Cheng J, 2018. Roles of seed components in the growth of barley seedlings under salt stress. Cereal Res. Commun. 46:436-47.

Zhu J, Fan Y, Li C, Shabala S, Zhao C, Hong Y, Lv C, Guo B, Xu R, Zhou M, 2020. Candidate genes for salinity tolerance in barley revealed by RNA-seq analysis of near-isogenic lines. Plant Growth Regul. 92:571-82. 